\title{
The Costs and Benefits of Monetary Integration Reconsidered: towards Value-Added Based Openness Measures
}

\author{
Ansgar Belke and Lars Wang \\ University of Hohenheim
}

\begin{abstract}
This study re-assesses regional integration by taking new measures for the degree of openness into account. The value-added based economic integration (VEI) model which improves on traditional economic integration models forms the core of these openness indicators. We show that a shift from the usual proxies of the gross economic integration (GEI) model towards those of the VEI model leads to a decrease of the realized degree of economic integration. Hence, the costs (benefits) are higher (lower) for a country from joining a fixed exchange rate area as supposed by the standard GEI model. From this perspective, the outcomes based on the traditional GEI model tend to overestimate the potential success of a given monetary integration process. More specifically, even a revision of the recommendation for a country to participate in a single currency area might be a consequence. Finally, empirical estimates of these new openness measures are delivered for more than twenty countries.
\end{abstract}

- JEL classifications: C67, E20, F15, F42

- Key words: Degree of economic integration, Exchange rate arrangement, Openness, Optimum currency areas, Value-added approach

\footnotetext{
*Corresponding address: Ansgar Belke, Department of Economics, University of Hohenheim Schlossof-Ost, D-70593 Stuttgart, Germany. Tel: +49-711-459-3246/7, Fax: +49-711-459-3815, E-mail: belke@unihohenheim.de. Lars Wang, Department of Economics University of Hohenheim Schlossof-Ost, D70593 Stuttgart, Germany

(c2006-Center for International Economics, Sejong Institution, All Rights Reserved.
} 


\section{Introduction}

This study presents the impact of a changed foundation of the cost-benefit analysis of monetary integration on the assessment of regional integration. A fundamental part of this analysis is a country's degree of economic integration, which plans to participate in a monetary integration process. According to the common perception, a high economic importance of inter-regional trade, i.e. a high degree of trade openness, indicates a high level of economic integration between two regions. The costs and the benefits from an economy's pegging of the domestic currency depend on the degree of economic integration. When benefits are larger than costs at a specific degree of economic integration a country should join the other members of a single currency area (Krugman and Obstfeld 2003, pp. 617).

However, the value of the degree of economic integration in the cost-benefit analysis of monetary integration depends on the operationalization of the economic significance of a country's trading partners within an integration area. Commonly, the regional export ratio (RER) of the gross economic integration (GEI) model is applied as the degree of economic integration. ${ }^{1}$ The RER index attempts to indicate a country's surplus production. In addition, it is supposed that the dependency of a country's residents on imports is measured by the regional import ratio (RIR) index (see, for example, Kotcherlakota and Sack-Rittenhouse, 2000). The interpretation of these trade shares sounds correct but these indices do not indicate what they are supposed to. These shares of trade are confusing because they do not take the international redistribution of income generated by trade into account. Exports do not exclusively create income in the country which sells goods and services to foreign countries as the export ratio states; they also engender income in the country's trading partners.

The RIR measure is criticized in a similar way to the argument of the export ratio. Residents of the home country are not dependent on all parts of imports as the index of openness suggests. They have to spend a lower portion of their income to purchase goods and services from abroad. Imports are partly produced with intermediate products delivered by other countries. These countries include the home country. Hence, international trading partners purchase intermediates from the domestic economy to assemble, for example, imports for the home country

\footnotetext{
${ }^{1}$ This economic integration measure puts regional exports in relation to the gross domestic product within a period of one year to indicate the importance of regional trade at the export side of a country. Furthermore, the regional import ratio measures the significance analogously at the import side.
} 
which, in turn, generates income for the domestic factors of production.

In contrast to the GEI model, the value-added based economic integration (VEI) model which is developed in this paper overcomes this limitation. Its measures of openness attempt to adjust the conventional indices through expressing trade in value-added terms instead of gross terms. This value-added based concept is in clear contrast to the mainstream. Common approaches adjust the gross domestic product, which very likely increases the accuracy of cross-country comparisons, but the fundamental difficulty of traditional openness indices remains untouched. The numerator is still expressed in gross terms whereas the denominator is stated in value-added terms.

This contribution proceeds as follows. Section II presents the theoretical framework of the cost-benefit analysis of monetary integration which has become popular in the last decades under the heading of optimum currency area theory to point out the significance of the degree of economic integration for this analysis. In section III, the value-added based economic integration model is developed. It serves as the theoretical foundation of our new empirical method to assess the economic relevance of regional trade linkages for an economy. Subsequently, section IV empirically outlines the VEI model's impact on the results of the standard costbenefit analysis of monetary integration and compares them to the outcomes of the well-known standard gross economic integration model. Our analysis covers the member countries of important regional integration areas as, e.g., EU, NAFTA, and MERCOSUR. Section V concludes and discusses the implications of the outcomes for future optimum currency area considerations and, more general, for the assessment of international monetary relations and the optimality of exchange rate arrangements between economies.

\section{The Degree of Economic Integration within the Analysis of Monetary Integration}

Consider an economy which has to decide about participation in a monetary integration process, let's say a single currency area. To make its choice, this economy might apply the regular framework of the cost-benefit analysis of monetary integration, derived from the theory of optimum currency areas (see, for instance, Mundell 1961, Gros and Thygesen 1998, pp. 268). Speaking more bluntly, it has to assess the potential benefits and costs of pegging its currency to a fixed exchange rate area (Krugman and Obstfeld 2003, pp. 617). 
The potential benefits for an economy of joining a single currency area are commonly perceived to materialize through perceivable gains in efficiency and credibility. The monetary efficiency gain occurs from pegging to a fixed exchange rate area instead of letting the exchange rate float since this tends to lower inflation differences and exchange rate volatility and, hence, transaction costs. Hence, the higher the degree of real economic integration of the economy in question with the existing integration area already is, the more the country in question will benefit from entering the single currency area.

The potential costs for a candidate from joining the currency area arise mainly through additional instability. Stabilization of output and, thus, also of employment becomes more difficult for an economy once the exchange rate does not float anymore vis-à-vis the currency area - the country gives up exchange rate and monetary policy to stabilize its economy. Exchange rate policy cannot influence relative prices of domestic and foreign products and monetary policy is not able anymore to effect domestic output anymore to adjust to a product demand or supply shock. Hence, the costs to be born by the economy are the lower the higher the degree of economic integration is because, in this case, the economy and the member countries of the integration area are supposed to respond in a similar fashion to shocks.

Figure 1 puts these considerations in a joint diagram which usually serves as a framework to decide whether an economy should join the monetary integration process (see, e.g., Krugman/Obstfeld 2003, pp. 604, which represents a useful summary of the work originally proposed by Krugman 1990 and de Grauwe 1994).

The figure's horizontal axis measures the economic integration of an economy

Figure 1. Cost-benefit analysis of a monetary integration

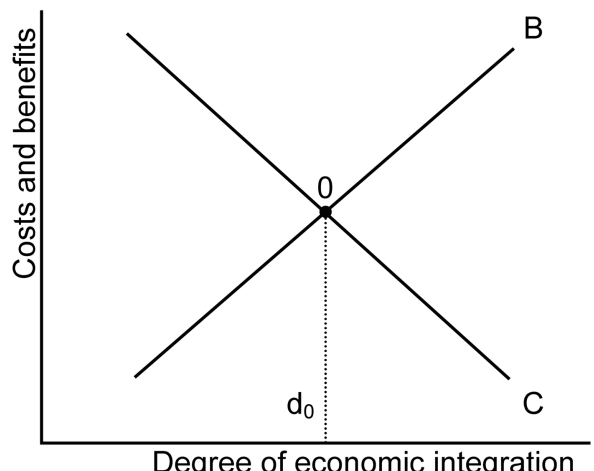

Degree of economic integration 
with other countries of a region. Benefits of the monetary efficiency and costs of the economic stability loss for the candidate are measured by the vertical axis. The realizations of all indicators increase from zero in the diagram's origin. Schedule B displays the relation between the degree of economic integration of an economy and the benefits from joining the area. $\mathrm{B}$ has a positive slope because an economy's benefits rise as its trade openness with that area increases. Schedule C reflects the relation between the degree of economic integration and the costs. Costs decrease the more the country is integrated with the area leading to a negative slope of $\mathrm{C}$. Figure 1 illustrates that the minimum degree of economic integration is $\mathrm{d}_{0}$ which is determined by the intersection of $\mathrm{B}$ and $\mathrm{C}$ in point 0 . When an economy's degree of economic integration equals $\mathrm{d}_{0}$ the country is indifferent with respect to its decision. With a level higher (lower) than $\mathrm{d}_{0}$ the country should (not) peg its domestic currency to a fixed exchange rate area. In this case, the potential benefits are (not) high enough to outperform the potential costs for a candidate of joining the integration area.

\section{Measurement of Economic Integration with the VEI Model}

In Section I, we discussed the potential drawbacks of the usual measures of economic integration. In this context, the question emerges how the analysis of monetary integration might be improved with more appropriate measures of economic integration. This question was the motivation for developing the VEI model in this paper. In any case, an answer should contain a major enhancement of the adequacy of the degree of economic integration with an eye on its heavy impact on the results of the cost-benefit analysis. In general, one should bear in mind that a high relevance of member countries of an integration area for an economy is associated with a high degree of openness with them.

In contrast to the output-orientation of the GEI model, our new value-added based economic integration model interprets the magnitude of countries within a region in an input-oriented way. Within this model, we focus on the production factors' income which the international trade generates in the producer country. Hence, the economic integration measures of the VEI model do not take the total value of regional trade into account. The regional value-added based export ratio (RVER) and the regional value-added based import ratio (RVIR) are the corresponding indicators. The RVER relates the domestic value added which is induced by regional exports of the home country to the GDP. Similarly, the RVIR 
measure compares the regional value added which is induced by regional imports of the home country with the GDP.

Within the VEI model, we model economic interdependencies by means of an input-output table which represents them in value terms. This input-output table illustrates that the output of economic sectors are the delivery of intermediate products to domestic sectors as well as to foreign sectors and the supply of goods and services to domestic and foreign final demand. The foreign sectors and the components of foreign final demand are located in economies within a region or outside of the considered region. In addition, economic sectors need input to produce their output. Hence, the VEI model presents these sectors' obtainment of intermediates from economic sectors at home and abroad. The imported intermediate inputs are split up with respect to the trading partners' location within an integration area or as part of the rest of the world. Besides these domestic and imported intermediate products, sectors also require domestic production factors for their production of output.

However, it is important to look at the assumptions which are made for modeling the connections between production output and its input. In general, it is supposed that every sector produces a homogenous product by using a homogenous technology. Hence, there is no necessity to distinguish between products and economic sectors. Furthermore, a proportional relation between total production of a sector and its essential intermediate products is assumed. Returns to scale are presumed to be constant in the production. That is, production coefficients are supposed to be independent from the factor input. The final demand is presumed to be exogenously given to allow the determination of economic sectors' total production. Finally, it is presupposed that a given production of a sector is only achievable by a combination of production factors. Consequently, possibilities of factor substitution do not exist at all. An efficient input of factors is only achievable if all sectors produce the amount of intermediates being required for the total production of the economic sector. ${ }^{2}$

\section{Potential Impacts of the VEI Model on the Analysis of Monetary Integration}

The comparative analysis enacted in this section has a closer look on the

${ }^{2}$ For a mathematical presentation of the VEI model refer to the technical appendix.. 
significance of the variations of calculated degrees of openness. This leads to the final interesting question whether differences between the degree of economic integration measured by the presented models reveal a sufficient magnitude to have a distinct impact on the results of the traditional cost-benefit analysis of monetary integration.

As a starting point of the empirical analysis we calculate and present the empirical realizations of the degrees of economic integration of 21 countries which are members of the EU, NAFTA, and MERCOSUR according to the different discussed measures. The GTAP Data Base Version 5.4 is the source of data (Dimaranan and McDougall 2002). ${ }^{3}$ The latest year for which a data set is available is 1997 . Table 1 displays the outcomes for the proxies of economic integration of the value-added based economic integration model as well as the gross economic integration model at the export and import side of the economies. A degree of economic integration of zero per cent of the gross domestic product indicates a closed economy which finds itself in a status of complete autarky. The higher the empirical value is, the more significant are the other member countries of an integration area with respect to their trade relationships for the country under consideration.

For example, trade activities of Argentina with its neighbors Brazil, Paraguay, and Uruguay are summarized by the country's degree of economic integration. Table 1 demonstrates that the results of the alternative economic integration measures range between 2.0 and 2.7 per cent of the GDP in the year 1997. For Argentina, both economic integration models reveal a very low level of regional trade openness as already assessed by Belke and Gros (2003). The country exports 2.7 per cent of all goods and services for the final demand to MERCOSUR (RER). According to the RVER measure, these exports lead to domestic income which amounts to 2.4 per cent of the total earnings in Argentina. Within the same year, the expense for imports from the region represents a share of 2.2 per cent of the national income (RIR). Only 2.0 per cent of the income which the domestic production factors receive is transferred to the other members of MERCOSUR since imports include exported intermediates which create income in Argentina (RVIR).

In the following, we search for systematic disparities between the empirical outcomes if different economic integration models are applied. Figure 2 gives a brief eye-ball impression of the empirical realizations of the degrees of openness of Table 1, dependent on the method used. The horizontal axis arranges the

${ }^{3}$ We do not include Paraguay in this cross-sectional sample simply because data were not available. 
Table 1. Degrees of economic integration based on the VEI and GEI mode-Empirical realizations for 1997

\begin{tabular}{|c|c|c|c|c|}
\hline \multirow{2}{*}{ Per cent of GDP, 1997} & \multicolumn{2}{|c|}{ Export side } & \multicolumn{2}{|c|}{ Import side } \\
\hline & RVER & RER & RVIR & RIR \\
\hline \multicolumn{5}{|l|}{ MERCOSUR } \\
\hline Argentina & 2.4 & 2.7 & 2.0 & 2.2 \\
\hline Brazil & 0.8 & 0.9 & 1.1 & 1.2 \\
\hline Paraguay & $\ldots$ & $\ldots$ & $\ldots$ & $\ldots$ \\
\hline Uruguay & 5.7 & 7.1 & 8.3 & 9.0 \\
\hline \multicolumn{5}{|l|}{ NAFTA } \\
\hline Canada & 19.2 & 27.1 & 20.0 & 22.5 \\
\hline Mexico & 17.7 & 23.2 & 16.3 & 18.2 \\
\hline United States & 2.2 & 2.6 & 2.4 & 3.3 \\
\hline \multicolumn{5}{|l|}{$\mathbf{E U}$} \\
\hline Austria & 14.8 & 21.1 & 23.4 & 26.8 \\
\hline Belgium & 24.8 & 48.4 & 42.3 & 48.6 \\
\hline Denmark & 16.1 & 21.7 & 18.0 & 20.7 \\
\hline Finland & 15.0 & 20.7 & 16.7 & 18.9 \\
\hline France & 11.8 & 14.5 & 12.1 & 14.3 \\
\hline Germany & 11.3 & 14.1 & 11.4 & 13.6 \\
\hline Greece & 6.7 & 7.8 & 14.4 & 16.3 \\
\hline Ireland & 29.3 & 49.8 & 37.2 & 41.9 \\
\hline Italy & 9.9 & 12.9 & 11.3 & 13.0 \\
\hline Luxembourg & 25.9 & 50.6 & 47.3 & 54.1 \\
\hline Netherlands & 25.7 & 42.1 & 27.4 & 31.0 \\
\hline Portugal & 16.1 & 21.7 & 26.1 & 30.3 \\
\hline Spain & 12.4 & 16.4 & 15.1 & 17.5 \\
\hline Sweden & 15.7 & 22.1 & 19.5 & 22.3 \\
\hline United Kingdom & 10.5 & 13.2 & 12.3 & 14.2 \\
\hline
\end{tabular}

Source: Dimaranan and McDougall (2002) and own calculations.

economies of the sample in an increasing order by their position within the rank order of the RER measure. The vertical axis displays the empirical outcomes of the regional value-added based export ratio and the regional export ratio.

Figure 2 illustrates that, first, the RVER is in all cases lower than the RER. Hence, the VEI model as a rule leads to lower measured degrees of economic integration as compared to the often applied and still popular GEI model. Second, Figure 2 clearly reveals the tendency of the RVER to increase with the RER. This means that the more products the economic sectors of an economy sell to their regional trading partners the more domestic production factors they and their 
Figure 2. Degrees of economic integration at the export side

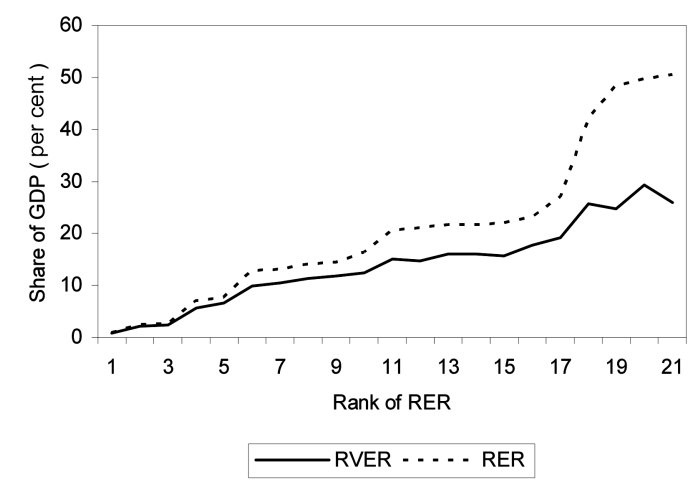

Source: Dimaranan and McDougall (2002) and own calculations.

previous supplying economic sectors need for production. The income of these input factors exactly corresponds to the export-induced domestic value added. Third, Figure 2 points out that the spread between the indicators RVER and RER increases with the rank order. This spread reflects the imported intermediate products which a country demands to produce exports as a share of the GDP. An increasing gap between the two measures reveals that a more regional open economy demands domestic production factors at a relatively lower magnitude. The more companies sell products on international markets the more firms are confronted with the pressure to reduce costs and the more of them gain experiences through exporting final products which let them include more cost-efficient primary inputs from abroad than those from home.

Fourth, the curve of the regional value-added based export ratio is less steep than the regional export ratio and, thus, the economies reveal smaller differences with respect to their degree of openness when the value-added based economic integration model is applied. This implies that the importance of regional trade is more similar for the countries within an integration area than the GEI model suggests. Fifth, the jitter of the economic integration measure RVER respectively the emergence of local maxima reflects that some positions of countries within the rank order change due to a shift in the measure of economic integration.

Figure 3 completes the overview of the Table 1 by focusing on the values of the proxies of openness at the countries' import side. The figure's horizontal axis puts the economies in an increasing order of their regional import ratio (RIR) values. From its vertical axis the empirical realizations of the regional value-added based 
Figure 3. Degrees of economic integration at the import side.

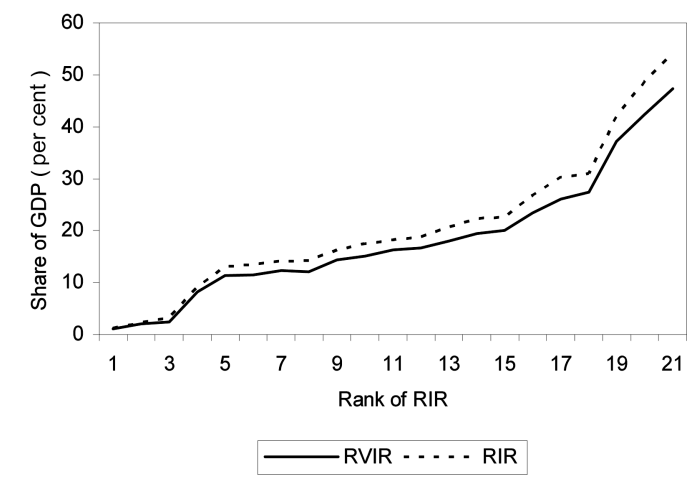

Source: Dimaranan and McDougall (2002) and own calculations.

import ratio and the regional import ratio can be read off. Figure 3 reveals that the results in principle correspond to those for the export side, but at a distinctively lower order.

We now proceed to an econometric evaluation of the results via a brief regression analysis. For this purpose, we analyze the indicators of the GEI model and the VEI model with a frequency distribution analysis in Table 2 . The standard statistical measures also include the Jarque-Bera test of a normality distribution (Jarque and Bera 1987).

Seen on the whole, thus, Table 2 confirms the previous outcomes. What additional insights between the relationship of regional trade and induced income can a

Table 2. Results of the frequency distribution analysis

\begin{tabular}{lcccc}
\hline \multirow{2}{*}{ Sample 1 21 Observations 21 } & \multicolumn{2}{c}{ Export side } & \multicolumn{2}{c}{ Import side } \\
\cline { 2 - 5 } & RVER & RER & RVIR & RIR \\
\hline Mean & 14.01 & 20.98 & 18.31 & 20.95 \\
Median & 14.78 & 20.67 & 16.25 & 18.24 \\
Maximum & 29.28 & 50.59 & 47.33 & 54.12 \\
Minimum & 0.84 & 0.94 & 1.08 & 1.19 \\
Range & 28.44 & 49.65 & 46.25 & 52.93 \\
Standard deviation & 8.05 & 15.21 & 12.38 & 14.11 \\
Variation coefficient & 0.57 & 0.72 & 0.68 & 0.67 \\
Skewness & 0.17 & 0.77 & 0.83 & 0.83 \\
Kurtosis & 2.29 & 2.64 & 3.17 & 3.20 \\
Jarque-Bera & 0.54 & 2.19 & 2.42 & 2.47 \\
Probability & 0.7648 & 0.3340 & 0.2980 & 0.2907 \\
\hline
\end{tabular}

Source: Dimaranan and McDougall (2002) and own calculations. 
regression analysis offer (Greene 2002)? It would appear that the following specifications of the regression equations are useful in our context:

$$
\begin{gathered}
\operatorname{logRVER}=\hat{c}_{1}+\hat{c}_{2} \operatorname{logRER}+\hat{u}_{t}, t=1,2, \ldots, 21 \text { and } \\
\operatorname{logRVER}{ }_{t}=\hat{c}_{1}+\hat{c}_{2} \operatorname{logRIR} \mathrm{u}_{t}+\hat{u}_{t}, t=1,2, \ldots, 21,
\end{gathered}
$$

where the index $t$ represents the economy with the number $t$ in the sample. The estimator $\hat{c}_{2}$ in equation (1) measures the induced percentage change of RVER when $\mathrm{RER}_{t}$ increases by one percent. Equation (2) has to be interpreted in an analogous fashion. We apply the ordinary least squares (OLS) method after making sure that the usual assumptions of functionality, of no autocorrelation, normality and homoscedasticity of the residuals are valid for the chosen specifications. Table 3 displays the final estimation results of equation (1).

The table supports the outcome of Figure 2 that the importance of domestic production factors in relation to imported intermediate products to produce goods and services for exports declines with the level of an economy's participation within the international division of labor. An increase of exports in relation to all products for final demand (RER) of 1.0 per cent increases the wealth at home for the same amount as the GEI model suggests. But these exports lead to an increase of only 0.87 per cent of income which domestic production factors earn (RVER).

For the import side, the regression analysis estimates an increase of the RVIR of 1.0 per cent when the RIR raises 1.0 per cent (see Table 4 ). This outcome clearly goes in line with that one of Figure 3, namely that the share of exported

\begin{tabular}{|c|c|c|c|c|}
\hline \multicolumn{2}{|c|}{ Dependent VariableLOG(RVER) } & \multicolumn{2}{|l|}{ Sample } & 121 \\
\hline \multicolumn{2}{|c|}{ Method Least Squares } & \multicolumn{2}{|c|}{ Included observations } & 21 \\
\hline Variable & Coefficient & Std. Error & $t$-Statistic & Prob. \\
\hline $\mathrm{C}$ & 0.033038 & 0.058531 & 0.564452 & 0.5791 \\
\hline$\overline{\mathrm{LOG}(\mathrm{RER})}$ & 0.872078 & 0.020420 & 42.70726 & 0.0000 \\
\hline$R$-squared & 0.989690 & Mean dep & & 2.373258 \\
\hline Adjusted $R$-squared & 0.989148 & S.D. deper & & 0.904943 \\
\hline S.E. of regression & 0.094272 & Akaike in & & -1.794866 \\
\hline Sum squared resid & 0.168858 & Schwarz c & & -1.695387 \\
\hline Log likelihood & 20.84609 & $F$-statistic & & 1823.910 \\
\hline Durbin-Watson stat & 0.965361 & $\operatorname{Prob}(F-$ sta & & 0.000000 \\
\hline
\end{tabular}

Table 3. Regression of value-added based economic integration at the export side

Source: Dimaranan and McDougall (2002) and own calculations. 
Table 4. Regression of value-added based economic integration at the import side

\begin{tabular}{lclcc}
\hline \multicolumn{1}{c}{$\begin{array}{c}\text { Dependent Variable } \\
\text { Method }\end{array}$} & $\begin{array}{c}\text { LOG(RVIR) } \\
\text { Least Squares }\end{array}$ & \multicolumn{2}{l}{$\begin{array}{l}\text { Sample } \\
\text { Included observations }\end{array}$} & \multicolumn{1}{c}{21} \\
\hline Variable & Coefficient & Std. Error & $t$-Statistic & Prob. \\
C & -0.150631 & 0.027835 & -5.411636 & 0.0000 \\
LOG(RIR) & 1.004423 & 0.009637 & 104.2224 & 0.0000 \\
$R$-squared & 0.998254 & Mean dependent var & 2.591568 \\
Adjusted $R$-squared & 0.998162 & S.D. dependent var & 0.970846 \\
S.E. of regression & 0.041622 & Akaike info criterion & -3.429974 \\
Sum squared resid & 0.032916 & Schwarz criterion & -3.330496 \\
Log likelihood & 38.01473 & F-statistic & 10862.31 \\
Durbin-Watson stat & 2.530844 & Prob $(F$-statistic $)$ & 0.000000 \\
\hline
\end{tabular}

Source: Dimaranan and McDougall (2002) and own calculations.

intermediates which are manufactured in the imports is at a similar low level for the countries and hence independent of the degree of economic integration.

In order to round off our analysis, the following part investigates the relevance of the findings for the cost-benefit analysis of monetary integration of the theory of optimum currency areas. According to the VEI model, the present members of a fixed exchange rate area and the possible participant are less economically integrated with each other than the popular standard GEI model suggests. Consequently, the candidate's assessment of the realized degree of economic integration is lower as well. Since the measures of the value-added based economic integration model indicate the significance of regional trading partners by focusing on income in the probable participant as well as the member countries which trade between them creates, the VEI model does not include trade with the rest of the world to the same extent as the GEI model does. We argued that the by now well-established gross economic integration model is not able to distinguish whether intermediate products for regional trade are delivered from suppliers within the integration area or outside the region. The GEI model overestimates the regional economic integration because it includes these extra-regional intermediates when an assessment of the trade importance of an integration area for a single pre-in country is on the agenda. In the same vein, this also implies that the GEI model attaches a too high impact of the regional integration on economic variables of the economies within a region.

Figure 4 illustrates the impact of a shift in the theoretical basis of the concrete degree of economic integration for an economy deciding to join a monetary integration area. ${ }^{4}$ In a very simplified stylized fashion, the diagram demonstrates 
Figure 4. Impact of the VEI model on the realized degree of economic integration

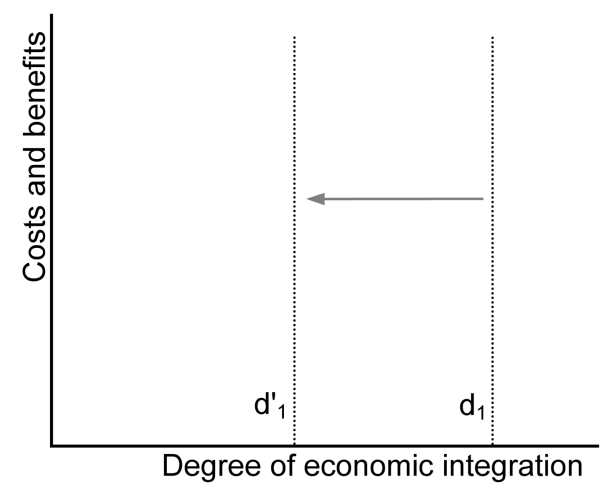

Figure 5. Impact of the VEI model on the judgment of joining an exchange rate area.

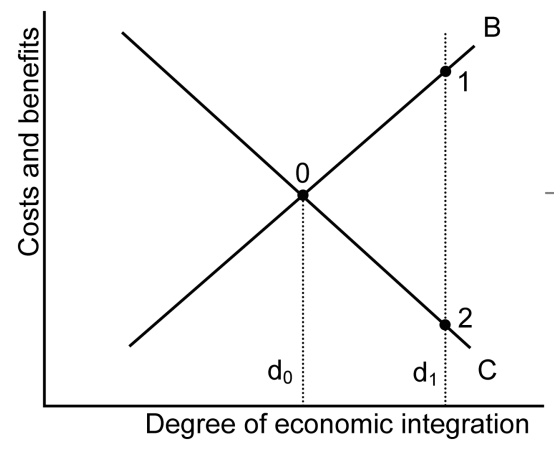

(a) GEI model based foundation

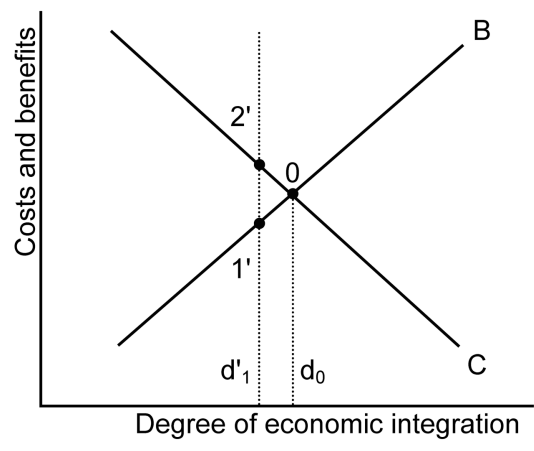

(b) VEI model based foundation

the move of the currently measured degree of economic integration from $d_{1}$ to the lower level $\mathrm{d}_{1}{ }_{1}$ when the VEI model is applied instead of the gross economic integration (GEI) model for measuring the significance of economies within a region.

When the VEI model is applied instead of the gross economic integration (GEI) model to measure the relevance of regional trade, a reassessment of a candidate's decision to join a fixed exchange rate area might be necessary. Figure 5 illustrates this straightforward outcome.

The diagram picks up the candidate's critical degree of openness $\mathrm{d}_{0}$ of Figure 1. Figure 5a displays a scenario in which an economy's actual degree of economic

\footnotetext{
${ }^{4}$ The following diagrams use the same cost-benefit framework as in Figure 1. For a description of their construction refer to section 2 .
} 
integration $\mathrm{d}_{1}$ is derived from the GEI model and is higher than its minimum (break-even) degree of economic integration represented by $\mathrm{d}_{0}$. Since the benefits of joining the fixed exchange rate area in point 1 outweigh the costs in 2 the result of this cost-benefit analysis of monetary integration is a recommendation for the economy to peg its currency to the fixed exchange rate area. Figure $5 \mathrm{~b}$ draws another conclusion for the same potential candidate facing an unchanged economic environment. A change of the underlying economic integration model towards the VEI model leads to an opposite recommendation than before with the GEI model. In this scenario of Figure $5 \mathrm{~b}$, the realized degree of economic integration $\mathrm{d}_{1}{ }_{1}$ is lower than the critical degree of economic integration $\mathrm{d}_{0}$. The benefits accruing from entering the currency area in point 1 ' are less than the costs in point 2'. Hence, the economy should not join the monetary integration process of the region. Seen on the whole, thus, outcomes of the cost-benefit analysis of monetary integration based on the value-added based economic integration model might deviate from those analysis results backed up by the GEI model. This seems to be a quite important policy conclusion from our derivation of value-added based indices of openness.

Are the differences of the calculated degrees of economic integration between the economic integration models significant enough to have a potential to influence the results of the integration areas' cost-benefit analysis of monetary integration? Since this study emphasizes the actual degree of economic integration and not the minimum level it is difficult to give an answer to this question. The critical levels are necessary to assess the influence of the value-added based economic integration model on the results of the cost-benefit analysis for an economy. Only a sound assessment of the break-even degree of economic integration based on exact identifications of the cost and the benefit curve is able to reveal whether in the concrete economic situation of a country benefits of joining the fixed exchange rate area surpass the costs. Belgium, Ireland, Luxembourg, and Netherlands might be candidates for a closer look because the deviations of actual degree of economic integration are of relevant size.

\section{Conclusions}

This paper develops a value-added measure for the degree of openness. Additionally, it argues that a change in the theoretical underpinnings of the degree of economic integration towards a more coherent definition potentially leads to a 
revision of the recommendation for a country to participate in a single currency area. Finally, it delivers empirical estimates of these new openness measures for more than twenty countries.

The standard cost-benefit OCA framework for a judgment whether a candidate country should join a fixed exchange rate area uses the degree of economic integration (openness) as an important determinant. If the realized degree of economic integration is higher than the break-even minimum degree of economic integration then the country should move towards entering the fixed exchange rate area. The realized degree of economic integration increases with the intensity of trade among the countries within an integration area.

In general, the degree of economic integration of a specific country is calculated based on an economic integration model which indicates the significance of its trading partners. The most popular economic integration model in this respect is the standard gross economic integration (GEI) model. It puts the economy's exports to (imports from) the member countries of an integration area in relation to all of its produced goods and services within the period of one year. This representation of the importance of regional trade linkages of the established gross economic integration model is at least questionable because of the poor linkage between the theoretical basis of its empirical economic integration measures. According to the gross economic integration model, a country that earns more income from exports than from the production of all final goods and services creates a negative income with non-tradeables.

The value-added based economic integration model developed in this contribution assures a more accurate and coherent calculation of the degree of economic integration. This approach does not take the total value of regional trade into account. One such indicator relates the domestic income which is generated by exports of the home country to the region to all products produced within a year. The other measure of economic integration highlights the share of income in the region which is created by imports of the home country from the region to all produced goods and services of the home country within one year. Imported intermediate products which are manufactured in exports, as well as exported intermediates which are part of imports are unfortunately separated since they do not create income in the producer country.

A change of the theoretical underpinnings of the degree of openness towards the new value-added based economic integration model shows that exports create less income in the producer country than the gross economic integration model 
suggests. Export sectors and their supplying sectors demand imported intermediates to produce exports which increase the wealth outside the country. Hence, we conclude that the gross economic integration model overestimates the realized degree of economic integration.

If the realized degree of economic integration becomes lower than even the minimum break-even degree of economic integration (which is totally possible in the wake of the shift from the gross economic integration model towards the valueadded based economic integration model), the recommendation for the candidate country to peg its currency to the fixed exchange rate area might have to be revised. This paper was not able to finally reveal whether this is actually the case for the integration areas EU, NAFTA, and MERCOSUR because it has its main focus on calculating the actual degrees of economic integration but not the critical ones. Nevertheless, already this very early stage of research indicates that it might be reasonable to think about changing the perspective from an output-oriented towards an input-oriented theoretical view when assessing the importance of trading partners within a region by means of the degree of economic integration.

How are our empirical results related to the issue of monetary integration? This is the key agenda in this contribution. We have shown that the outcomes of the cost-benefit analysis of monetary integration based on the traditional gross economic integration model are biased towards indicating net benefits of joining a fixed exchange rate area too often. This has been demonstrated by showing that the value-added based economic integration model throughout leads to a decrease of the empirical realization of the standard measure of the degree of economic integration. In other words, the exposure to foreign trade in general and the degree of economic integration between the joining country and the exchange rate area are lower than usually assumed in standard optimum currency area theory. Hence, also the net benefits of joining fixed exchange rate regimes are generally smaller than sometimes suggested by politicians. One of the reasons is that the economic stability loss for the joining country is higher since less actual integration implies more costly adjustment to adverse shifts in country-specific demand, i.e. to asymmetric shocks. This seems to be a quite important policy conclusion from our derivation of value-added based indices of openness.

Further research should try to calculate a candidate's minimum break-even degree of economic integration which is derived from costs and benefits of joining a fixed exchange rate area. Its comparison with the actual level of trade within the region would give a further hint whether the country should participate or not. In 
the same vein, a systematic comparison between the significance of trading partners inside a region and those outside of it could reveal additional insights about the intensity of integration within an integration area with respect to trade. An advanced version of the value-added based economic integration model proposed in this paper could give additional insights in the structure of international trade based on newly developed structural integration measures. This version could be more concrete in describing, for example, the traded products, the demanding sources, and the incorporated production factors. ${ }^{5}$ Finally, an enlarged country sample, including more integration areas as well as additional years, should enrich the work further.

Received 10 August 2004, Accepted 5 September 2005

\section{References}

Belke, A., Gros, D. (2003), The Cost of Financial Market Variability in the Southern Cone, Revue Economique, 54(5), 1091-1116.

de Grauwe, P. (1994), The Economics of Monetary Integration, Oxford University Press, Oxford, $1^{\text {st }}$ and further eds.

Dimaranan, B.V., McDougall, R.A. (2002), Global Trade, Assistance, and Production: The GTAP 5 Data Base, Center for Global Trade Analysis, Purdue University, West Lafayette.

Greene, W.H. (2002), Econometric Analysis, 5th Ed., Upper Saddle River.

Gros, D., Thygesen, N. (1998), European Monetary Integration, 2nd Ed., Harlow.

Jarque, C.M./Bera, A.K. (1987), A Test for Normality of Observations and Regression Residuals, in: International Statistical Review, 55, 163-172.

V., Sack-Rittenhouse Kotcherlakota, M. (2000), Index of Openness: Measurement and Analysis, in: Social Science Journal, 37(1), 125-130.

Krugman, P.R. (1990), Policy Problems of a Monetary Union, in: de Grauwe, P., Papademos,

L. (eds.), The European Monetary System in the 1990s, Centre for European Policy Studies and Bank of Greece, 48-64.

Krugman, P. R., Obstfeld, M. (2003), International Economics: Theory and Policy, 6th Ed., Reading, MA.

Mundell, R.A. (1961), A Theory of Optimum Currency Areas, in: American Economic Review, 51(4), 657-665.

\footnotetext{
${ }^{5}$ Exports get delivered to final demand as well as to economic sectors by using intermediates to produce goods and services for the own country or economies abroad.
} 


\section{Technical Appendix}

\section{A. Economic interrelations}

We start our illustration of the input-output table of the value-added based economic integration model with a brief description of the output of sectors. The value of the gross output of sector $i$ of region $k\left(X_{i k}\right)$ is determined by the value of intermediate products of sector $i$ of region $k$ for all sectors $j$ of region $k\left(X_{i j k k}\right)$ and the value of goods and services of sector $i$ of region $k$ for all components $e$ of final demand of region $k$, including exports, $\left(Y_{\text {iekk }}\right)$ as

$$
X_{i k}=\sum_{j=1}^{4} X_{i j k k}+\sum_{e=1}^{3} X_{i e k k}, i=1,2,3,4, k=1,2,3 .
$$

Region $k$ consists of home country (1), aggregated integration area (2), or aggregated rest of the world (3). The aggregated region represents all regional trading partners of the home country and the aggregated rest of the world includes those economies outside the region. Sector $i$ and sector $j$ symbolize agriculture (1), other primary production (2), manufacturing (3), or services (4). Demand $e$ is that one in the home country (1), in the aggregated integration area (2), or in the aggregated rest of the world (3). Furthermore, economic sectors are in need of some input to produce some output. The value of the gross output of sector $j$ of region $k\left(X_{j k}\right)$ contains the value of delivered domestic intermediate products $\left(X_{i j k k}\right)$, the value of imported intermediate products of all sectors $i$ of region $l$ for sector $j$ of region $k\left(X_{i j k}\right)$, and the value of domestic production factors of all factors $g$ of sector $j$ of region $k\left(\mathrm{~W}_{g j k}\right)$ as

$$
X_{i k}=\sum_{i=1}^{4} X_{i j k k}+\sum_{i=1}^{4} \sum_{l \in k} X_{i j l k}+\sum_{g=1}^{5} W_{g j k}, \quad j=1,2,3,4, \quad k=1,2,3
$$

where region $l$ represents home country (1), aggregated integration area (2), or aggregated rest of the world (3). Production factor $g$ is unskilled labor (1), skilled labor (2), capital (3), land (4), or natural resources (5). Therefore, the value of gross output in equation (3) equals that one in equation (4) because production output is of the same value as its input

$$
X_{i k}=X_{j k}, i, j=1,2,3,4, k=1,2,3 .
$$


This relation leads to an additional presentation of the link between the gross output and the demand as given in (3). The direct production coefficient of region $k$ $\left(a_{i j k}\right)$ gets introduced as

$$
a_{i j k}=\frac{X_{i j k k}}{X_{j k}}, i, j=1,2,3,4, k=1,2,3
$$

which indicates the value of required intermediate products of sector $i$ of region $k$ for sector $j$ of region $k$ to produce one unit output of sector $j$ of region $k$. (3) can be transformed into

$$
X_{i k}=\sum_{j=1}^{4} a_{i j k} X_{j k}+\sum_{e=1}^{3} Y_{i e k k}, i=1,2,3,4, k=1,2,3 .
$$

Finally, the gross domestic product of region $k\left(Y_{k}\right)$ coincides with the value of domestic primary inputs of region $k\left(W_{g j k}\right)$ as

$$
Y_{k}=\sum_{g=1}^{5} \sum_{j=1}^{4} W_{g / k}, \quad k=1,2,3 .
$$

Equations (3) to (8) represent the economic linkages within an economy, within its aggregated trading partners inside and outside an integration area, and between them. The next section analysis these interconnections.

\section{B. Modeling the income created by regional trade}

Assume that the home country's export sectors sell goods and services to member countries of an integration area. ${ }^{6}$ These exports generate income which equals the exports' value - the export-induced value added. According to equations (4) and (7), intermediate inputs from domestic economic sectors, imported intermediates from sectors inside and outside the integration area, and production factors of the home country are necessary for the production of these exports. Hence, exports do not only create income in the home country but also abroad via imported intermediate inputs. Production structures of export sectors and their supplying sectors reflect the international competitive position of these sectors and, hence, the degree of the economy's participation in the international division of labor. The export-induced domestic value added represents the value of required

${ }^{6}$ This view can be analogously applied to the aggregated integration area and aggregated rest of the world. 
production factors in the home country whereas the export-induced international value added characterizes its demand of imported intermediate products from the integration area (which has been aggregated over regions) or from the aggregated rest of the world.

In order to give a satisfying answer to the question how much income is created at home by exports of the producer country we start with a presentation of the gross output of equation (7) in a compact way. ${ }^{7}$ Hence, the vector of values of gross output of region $k\left(x_{k}\right)$ is

$$
x_{k}=\left(X_{1 k}, X_{2 k}, X_{3 k}, X_{4 k}\right)^{T}, k=1,2,3 \text {. }
$$

Then, the vector of final demand values of region $k\left(\mathrm{y}_{k}\right)$ is defined as

$$
y_{k}=\left(\sum_{e=1}^{3} Y_{1 e k k}, \sum_{e=1}^{3} Y_{2 e k k}, \sum_{e=1}^{3} Y_{3 e k k}, \sum_{e=1}^{3} Y_{4 e k k}\right)^{T}, k=1,2,3
$$

which is followed by the matrix of direct production coefficients of region $k\left(A_{k}\right)$

$$
A_{k}=\left(a_{i j k}\right)=\left(\begin{array}{cccc}
a_{11 k} & a_{12 k} & a_{13 k} & a_{14 k} \\
a_{21 k} & a_{22 k} & a_{23 k} & a_{24 k} \\
a_{31 k} & a_{32 k} & a_{33 k} & a_{34 k} \\
a_{41 k} & a_{42 k} & a_{45 k} & a_{44 k}
\end{array}\right), k=1,2,3 .
$$

Now, the gross output of equation (7) can be rewritten as

$$
x_{k}=A_{k} x_{k}+y_{k}, k=1,2,3 .
$$

The next intermediate step links the demanded exports with the required gross output of region $k\left(x_{k}\right)$. It begins with the vector of export values of region $k\left(y_{k}\right)$ which is defined as

$$
y_{k}=\left(Y_{1 l k k}, Y_{2 l k k}, Y_{3 l k k}, Y_{4 l k k}\right)^{T}, k=1,2,3, \quad l \notin k^{8}
$$

\footnotetext{
${ }^{7}$ This is named the export-induced domestic value added of region $k$.
} 
The identity matrix $(B)$ is

$$
B=\left(b_{r s}\right)=\left(\begin{array}{llll}
1 & 0 & 0 & 0 \\
0 & 1 & 0 & 0 \\
0 & 0 & 1 & 0 \\
0 & 0 & 0 & 1
\end{array}\right), b_{r s}=\left\{\begin{array}{l}
1 \text { for } r=s \\
0 \text { for } r \neq s
\end{array}\right.
$$

which allows to rearrange equation (12) to

$$
\left(B-A_{k}\right) x_{k}=y_{k}, \quad k=1,2,3 .
$$

As a result, the gross output of region $k\left(x_{k}\right)$, required to supply the exports of region $k\left(y_{k}\right)$, is

$$
x_{k}=\left(B-A_{k}\right)^{-1} y_{k}, \quad k=1,2,3 .
$$

The term $\left(B-A_{1}\right)^{-1}$ represents the Leontief inverse matrix of region $k$. Its coefficients indicate the expenditure of sector $i$ of region $k$ for the production of one unit final demand of sector $j$ of region $k$. It follows directly from the last step connecting the gross output of region $k\left(x_{k}\right)$ with the income of production factors in region $k$. The production coefficient of production factors $\left(d_{g j k}\right)$ is introduced as

$$
d_{g j k}=\frac{W_{g j k}}{X_{j k}}, \quad g=1,2, \ldots, 5, \quad j=1,2,3,4, \quad k=1,2,3
$$

indicating the value of factor $g$ necessary for the production of one unit output of sector $j$ of region $k$. Hence, the matrix of production coefficients of production factors of region $k\left(D_{k}\right)$ is

$$
D_{k}=\left(d_{g j k}\right)=\left(\begin{array}{llll}
d_{11 k} & d_{12 k} & d_{13 k} & d_{14 k} \\
d_{21 k} & d_{22 k} & d_{23 k} & d_{24 k} \\
d_{31 k} & d_{32 k} & d_{33 k} & d_{34 k} \\
d_{41 k} & d_{42 k} & d_{43 k} & d_{44 k} \\
d_{51 k} & d_{52 k} & d_{53 k} & d_{54 k}
\end{array}\right), k=1,2,3 .
$$

${ }^{8}$ Depending on the analysis' focus, either economies in one of the regions or all foreign countries, demanding exports, are taken into account. 
This leads us to the vector of values of production factors of region $k\left(q_{k}\right)$ which is defined as

$$
q_{k}=\left(Q_{1 k}, Q_{2 k}, Q_{3 k}, Q_{4 k}, Q_{5 k}\right)^{T}, \quad k=1,2,3
$$

This vector represents the values of production factors of region $k\left(q_{k}\right)$ for the gross output of region $k\left(x_{k}\right)$ required to supply the demanded export products of region $k\left(y_{k}\right)$

$$
q_{k}=D_{k} x_{k}, \quad k=1,2,3 .
$$

The symbol $q_{k}$ characterizes the export-induced domestic value added of region $k$.

In the following, the value of imported intermediates which the producer country creates with its exports is of main interest. ${ }^{9}$ Our efforts to link the gross output of region $k\left(x_{k}\right)$ with the value of imported intermediates from region $l$ start with the production coefficient of imported intermediate products $\left(c_{i j l k}\right)$

$$
c_{i j l k}=\frac{X_{i j l k}}{X_{j k}}, i, j=1,2,3,4, k=1,2,3,1 \notin k .
$$

Here, $\mathrm{c}_{i j l k}$ represents the value of intermediate products of sector $i$ of region $k$, required to be imported from region $l$, for the production of one unit output of sector $j$ of region $k$. The matrix of production coefficients of imported intermediate products of region $k$ from region $l\left(C_{l k}\right)$ is

$$
C_{l k}=\left(c_{i j l k}\right)=\left(\begin{array}{cccc}
c_{11 k} & c_{12 k} & c_{13 k} & c_{14 k} \\
c_{21 k} & c_{22 k} & c_{23 k} & c_{24 k} \\
c_{31 k} & c_{32 k} & c_{33 k} & c_{34 k} \\
c_{41 k} & c_{42 k} & c_{43 k} & c_{44 k}
\end{array}\right), k=1,2,3, l \notin k
$$

resulting in the vector of values of imported intermediate products of region $k$ from region $l\left(p_{l k}\right)$ where

${ }^{9}$ This is the value added which exports of the producer country $k$ generate abroad in region $l$ represented by the export-induced international value added of region $k$ in region $l$. 


$$
p_{l k}=\left(P_{1 l k}, P_{2 l k}, P_{3 l k}, P_{4 l k}\right)^{T}, k=1,2,3, l \notin k
$$

stands for the values of the required imported intermediates of region $k$ from region $l\left(p_{l k}\right)$ for the gross output of region $k\left(x_{k}\right)$ being essential to produce the export products of region $k\left(\mathrm{y}_{k}\right)$

$$
p_{l k}=C_{l k} x_{k}, k=1,2,3, l \notin k \text {. }
$$

$p_{l k}$ symbolizes the export-induced international value added of region $k$ in region $l$.

\section{Calculating the degree of economic integration}

The input-output table and the input-output analysis of the previous sections offer the necessary instruments to develop the economic integration measures RVER and RVIR of the value-added based economic integration model. The regional value-added based export ratio measure defines the importance of a country's trading partners within an integration area as the export-induced domestic value added of exports to the integration area $\left(q_{1}\right)$ as share of the gross domestic product $\left(Y_{1}\right)$ in percent as

$$
\begin{aligned}
& y_{1}=\left(Y_{1211}, Y_{2211}, Y_{3211}, Y_{4211}\right)^{T}, x_{1}=\left(B-A_{1}\right)^{-1} y_{1}, q_{1}=D_{1} x_{1} \\
& \operatorname{RVER}=\frac{q_{1}}{Y_{1}} 100 .
\end{aligned}
$$

In addition, the degree of economic integration can be calculated by focusing on the import side of a country. In this case, the indicator regional value-added based import ratio puts the export-induced regional value added $\left(q_{2}\right.$ and $\left.p_{23}\right)$ in relation to the GDP $\left(Y_{1}\right)$ in percent as

$$
\begin{aligned}
& y_{2}=\left(Y_{1122}, Y_{2122}, Y_{3122}, Y_{4122}\right)^{T}, x_{2}=\left(B-A_{2}\right)^{-1} y_{2}, q_{2}=D_{2} x_{2}, \\
& y_{3}=\left(Y_{1133}, Y_{2133}, Y_{3133}, Y_{4133}\right)^{T}, x_{3}=\left(B-A_{3}\right)^{-1} y_{3}, q_{23}=C_{23} x_{3}, \\
& \text { RVIR }=\frac{q_{2}}{Y_{1}} 100+\frac{q_{23}}{Y_{1}} 100 .
\end{aligned}
$$

The export-induced regional value added consists of the income created in the 
integration area by international trade with the home country. The variable $\mathrm{q}_{2}$ represents the export-induced domestic value added of the region aggregated integration area of exports to the region home country and $\mathrm{p}_{23}$ symbolizes the export-induced international value added of the region aggregated rest of the world in the region aggregated integration area. 